\title{
ANALISIS KEMUNCULAN ASPEK KETERPADUAN DAN PENGUASAAN KONSEP TERPADU SISWA SEKOLAH DASAR MELALUI KTSP DAN KURIKULUM 2013
}

\begin{abstract}
Rika Solihah $^{1}$
ABSTRAK

Penelitian ini bertujuan untuk mengetahui sejauh mana kemunculan aspek keterpaduan yang dilakukan oleh guru dan pencapaian penguasaan konsep terpadu siswa kelas IV SD melalui KTSP dan Kurikulum 2013 pada IPA konsep sumber daya alam. Penelitian ini dilakukan secara kualitatif dengan metode deskriptif dengan sampel dua SD yang menggunakan KTSP dan dua SD Kurikulum 2013. Instrumen yang digunakan berupa software videograph untuk menganalisis kemunculan aspek keterpaduan dan tes penguasaan konsep terpadu berupa soal pilihan ganda. Berdasarkah hasil kemunculan aspek keterpaduan dalam proses pembelajaran baik KTSP maupun Kurikulum 2013 masih sedikit dalam memunculkan aspek keterpaduan. Sedangkan perhitungan t' untuk tes penguasaan konsep terpadu KTSP lebih baik daripada Kurikulum 2013. Kesimpulan dalam penelitian ini bahwa pembelajaran terpadu tidak hanya dalam kurikulum 2013 saja, tetapi dalam KTSP pun yang pembelajarannya masih disipliner pembelajaran terpadu dapat dimunculkan.
\end{abstract}

Kata kunci: Aspek keterpaduan, penguasaan konsep terpadu, KTSP, dan kurikulum 2013

\section{A. PENDAhuluan}

Indonesia telah melakukan beberapa kali pergantian kurikulum, yang terbaru adalah pergantian Kurikulum Tingkat Satuan Pendidikan (KTSP) ke Kurikulum 2013. Salah satu perubahan esensial antara Kurikulum 2013 dan KTSP adalah penggunaan pembelajaran terpadu di tingkat sekolah dasar. Pada KTSP pembelajaran terpadu (tematik) hanya dilaksanakan di kelas rendah saja yaitu kelas 1 sampai kelas 3 sedangkan di kurikulum 2013 pembelajaran terpadu (tematik-integratif) dilaksanakan dari kelas 1 sampai kelas 6. Menurut BNSP (2006:35) penetapan pendekatan tematik pada siswa sekolah dasar terutama untuk peserta didik pada kelas rendah dilakukan karena pada umumnya siswa pada usia tersebut berada pada tingkat perkembangan yang masih melihat segala sesuatu sebagai suatu keutuhan (holistik), dan baru mampu memahami hubungan antar konsep secara sederhana.

Hal tersebut sesuai dengan landasan teori pembelajaran terpadu yang dikemukakan oleh Gestalt (dalam Sanjaya, 2010, hlm. 242) bahwa belajar adalah proses mengembangkan insight. Insight adalah pemahaman terhadap hubungan antar bagian di dalam suatu situasi permasalahan. Psikologi Gestalt sangat peduli

\footnotetext{
${ }^{1}$ Guru Sekolah Dasar di Jawa Barat
} 
terhadap perkembangan anak secara total tanpa memilih dan memilah antara unsur pengetahuan, keterampilan dan sikap. Selain itu proses perancangan pembelajaran terpadu menurut Yani (2014, hlm. 115) mirip dengan pembelajaran bermakna (meaningful learning) karena berusaha mengaitkan berbagai konsep yang tersebar di antara mata pelajaran yang dipelajari. Hasil rancangan pembelajaran terpadu akan membentuk suatu skema yang berisi keterkaitan antar mata pelajaran dalam bentuk jaring tema. Bagi guru akan nampak seperti mind map tetapi bagi siswa akan memperoleh pengetahuan secara tidak terpilah akan tetapi terasa utuh dan kebulatan pengetahuan (holistik).

Pergantian Kurikulum menimbulkan pro dan kontra karena kemunculannya terkesan tergesa-gesa. Meskipun demikian secara konseptual, banyak hal bagus dalam Kurikulum 2013, salah satunya adalah keseriusan pemerintah untuk menerapkan tematik integratif. Hal tersebut dibuktikan dengan diterbitkannya buku guru dan buku siswa. Hal ini dilakukan untuk meringankan tugas guru dalam membuat perangkat administrasi pembelajaran sehingga guru lebih fokus untuk melaksanakan pembelajaran. Selain itu, buku pegangan siswa dapat membatasi perdagangan buku teks di sekolah sehingga siswa tidak dituntut untuk membeli buku paket ataupun LKS. Buku panduan guru di dalamnya mencakup kompetensi dasar, tema, langkah-langkah pembelajaran dan penilaian yang harus dilakukan guru. Buku panduan guru ini memberikan jaminan terhadap kualitas/bahan ajar dan penyajian buku serta bahan bagi pelatihan guru dalam keterampilan melakukan pembelajaran dan penilaian pada proses serta hasil belajar peserta didik. Jika guru mengikuti mengikuti petunjuk yang ada dalam buku tersebut, pemerintah yakin guru dapat menerapkan pembelajaran terpadu di kelas. Namun terdapat beberapa hal yang dikhawatirkan dalam implementasi kurikulum 2013, salah satunya dikemukakan oleh Samsuri (2013, hlm. 10) tentang ketercakupan tema yaitu dalam hal mereduksi kajian multidisipliner/interdisipliner pada tema tertentu. Dikhwatirkan terdapat reduksi materi dari beberapa mata pelajaran, karena tidak sesuai dengan tema yang telah ditentukan. Terdapat juga hasil wawancara yang dilakukan oleh Maryeni (2014, hlm. 2) berdasarkan hasil wawancara bahwa implementasi kurikulum 2013 belum bisa dilaksanakan secara maksimal, terutama di kelas IV. Hal ini disebabkan guru kelas IV belum siap untuk menggunakan pembelajaran tematik terpadu dalam proses pembelajaran karena dengan latar belakang guru kelas IV adalah guru kelas yang sebelumnya mengajar berdasarkan bidang studi. Guru kelas IV mengalami kesulitan untuk mengimplementasikan pembelajaran tematik terpadu, diduga guru kelas IV belum memahami pembelajaran tematik terpadu dalam hal mempersiapkan materi pembelajaran tematik terpadu, kesulitan untuk membuat rancangan pembelajaran tematik terpadu dan belum tepat dalam menggunakan strategi dalam proses pembelajaran terpadu, di mana isi pelajaran diajarkan dengan strategi pembelajaran secara terpisah. Jadi walaupun pemerintah telah memberikan fasilitas berupa buku panduan guru, ternyata guru masih merasa kesulitan dalam hal mengikuti langkah-langkah pembelajaran terpadu yang ada dalam buku panduan guru. Sehingga guru harus memikirkan cara menyampaikan pembelajaran agar terlaksana secara utuh tidak terlihat pemisah antar mata pelajaran. 
Sedangkan untuk KTSP sendiri instruksi pembelajaran terpadu terdapat dalam Permendiknas nomor 22 tahun 2006, dalam struktur kurikulum KTSP pembelajaran pada kelas I sampai dengan III sekolah dasar dilaksanakan melalui pendekatan tematik. Substansi mata pelajaran IPA dan IPS merupakan "IPA Terpadu" dan "IPS Terpadu". Pada kurikulum ini pemerintah tidak memberikan buku panduan untuk guru dalam melaksanakan pembelajaran terpadu, guru diberikan kewenangan untuk menentukan tema dan kompetensi yang akan dipadukan dalam pembelajarannya. Oleh karena itu banyak ditemukan kesulitan baik dalam persiapan maupun pelaksanaan pembelajaran terpadu di KTSP. Menurut penelitian yang dilakukan oleh Pudjiastuti (2011) terdapat beberapa permasalahan dalam penerapan pembelajaran tematik di kelas awal sekolah dasar. Pertama, permasalahan persiapan pembelajaran tematik antara lain : (1) Guru kesulitan dalam mengembangkan tema dan contoh tema tidak selalu sesuai dengan kondisi lingkungan belajar siswa; (2) Guru kesulitan cara melakukan pemetaan Kompetensi Dasar yang terkait dengan tema; (3) Guru kesulitan dalam merumuskan keterpaduan berbagai mata pelajaran pada langkah pembelajaran dalam Rencana Pelaksanaan Pembelajaran (RPP). Kedua, permasalahan pelaksanaan pembelajaran tematik antara lain : (1) Bahan ajar yang tersedia masih menggunakan pendekatan mata pelajaran sehingga menyulitkan guru memadukan materi sesuai tema; (2) Bahan ajar tematik masih bersifat nasional sehingga beberapa materi kurang sesuai dengan kondisi lingkungan belajar siswa.

Berdasarkan hal di atas peneliti ingin mengetahui seberapa jauh kesesuaian antara teori pembelajaran terpadu yang ditetapkan pada kurikulum KTSP dan Kurikulum 2013 dengan penerapannya di lapangan. Hasil penelitian ini juga dapat memberikan data empirik baik untuk pemerintah maupun praktisi di bidang pendidikan tentang implementasi pembelajaran terpadu yang digunakan di KTSP dan Kurikulum 2013.

\section{B. METODE}

Penelitian ini dilakukan untuk memperoleh gambaran kemunculan aspek keterpaduan dan penguasaan konsep terpadu pada sekolah yang menggunakan KTSP dan kurikulum 2013. Berdasarkan hal tersebut metode yang digunakan dalam penelitian ini adalah metode kualitatif deskriptif. Pemilihan sampel penelitian ini dilakukan dengan menggunakan teknik purposive sampling, dimana sampel ditentukan sesuai dengan kriteria permasalahan penelitian, yaitu sekolah yang menggunakan kurikulum 2013 dan kurikulum KTSP. Pada tahun pelajaran 2013/2014 kurikulum 2013 baru diterapkan pada beberapa sekolah saja, begitu pula dengan kota Cirebon hanya terdapat 4 sekolah yang menggunakan kurikulum 2013 sedangkan sekolah lainnya masih menggunakan kurikulum KTSP. Berdasarkan pada fakta tersebut maka peneliti memilih 2 sekolah yang menggunakan kurikulum 2013 dan 2 sekolah yang menggunakan KTSP.

Instrumen dalam penelitian ini adalah observasi dan soal. Data observasi di deskripsikan dengan bantuan analisis video yang menggunakan software videograph. Adapun langkah-langkah analisis video dengan videograph adalah sebagai berikut.

a. Software videograph di operasikan di laptop dengan window 7. 
b. Hasil rekaman video berbentuk file di convert supaya dapat digunakan pada software videograph.

c. Membuka aplikasi videograph kemudian menuliskan kode untuk setiap aspek dan indikator yang akan di observasi dalam video pembelajaran.

d. Mengamati semua kegiatan guru apa adanya dari video tanpa diedit ataupun dipotong, kemudian memberikan kode pada aspek keterpaduan yang muncul

e. Menuliskan kejadian yang berkaitan dengan kemunculan aspek terpadu sebagai bahan mendeskripsikan kemunculan aspek keterpaduan dalam pembelajaran

f. Data dalam video ditransfer ke software SPSS versi 20 untuk dianalisis frekuensi kemunculan aspek keterpaduan.

Sementara itu, untuk soal penguasaan konsep terpadu setelah diuji cobakan dan dilakukan uji validitas, realibilitas, daya pembeda dan tingkat kesukaran. Soal tersebut kemudian dilanjutkan pada penelitian sebenarnya. Hasil jawaban siswa pada tes penguasaan konsep terpadu dianalisis dengan menggunakan rumus untuk mengetahui pencapaian nilai siswa. Selanjutnya dilakukan Analisis uji kesamaan rerata hasil tes yang bertujuan untuk memeriksa ada tidaknya perbedaan yang signifikan penguasaan konsep terpadu antara kelas KTSP dan kurikulum 2013.

\section{HASIL PENELITIAN}

Dalam proses analisis yang pertama, yaitu kemunculan aspek keterpaduan terdapat tiga aspek yang diamati, yaitu integrasi hakikat IPA, hubungan IPA dengan mata pelajaran lain dan hubungan IPA dengan kehidupan sehari-hari dan potensi daerah setempat. Subjek yang diteliti adalah guru, peneliti mengamati sejauh mana guru dapat memberikan stimulus kepada anak agar aspek-aspek keterpaduan tersebut muncul dalam pembelajaran baik itu di sekolah yang menggunakan KTSP maupun Kurikulum 2013. Penelitian terhadap pembelajaran di sekolah yang menggunakan KTSP dilakukan pada dua sekolah, guru yang mengajar pada dua sekolah tersebut diberi kode G1 dan G2, pembelajaran yang diamati sebanyak tiga pertemuan (210 menit) dengan rincian dua jam pelajaran pada setiap pertemuan. Penelitian di sekolah yang menggunakan kurikulum 2013 juga dilakukan pada dua sekolah, guru yang mengajar diberi kode G3 dan G4, pembelajaran yang diamati sebanyak lima pertemuan (900 menit) dengan rincian enam jam pembelajaran pada setiap pertemuan. Tabel di bawah ini adalah hasil analisis kemunculan aspek keterpaduan dengan menggunakan software videograph, angka-angka persentase pada tabel merupakan rata-rata dari setiap aspek keterpaduan.Rata-rata tersebut merupakan hasil bagi dari jumlah kemunculan setiap aspek dengan seluruh durasi pembelajaran.

Tabel 1 Rekapitulasi Kemunculan Aspek Keterpaduan

\begin{tabular}{|c|c|c|c|c|c|c|c|}
\hline \multirow[b]{2}{*}{$\begin{array}{c}\text { Jenis } \\
\text { Integrasi }\end{array}$} & \multirow[b]{2}{*}{$\begin{array}{c}\text { Aspek } \\
\text { Keterpaduan }\end{array}$} & \multicolumn{3}{|c|}{ KTSP } & \multicolumn{3}{|c|}{ KURIKULUM 2013} \\
\hline & & $\begin{array}{l}\mathrm{G} 1 \\
\%\end{array}$ & $\begin{array}{c}\mathrm{G} 2 \\
\%\end{array}$ & $\begin{array}{c}\text { Rata- } \\
\text { rata } \\
\%\end{array}$ & $\begin{array}{c}\text { G3 } \\
\%\end{array}$ & $\begin{array}{c}\mathrm{G} 4 \\
\%\end{array}$ & $\begin{array}{c}\text { Rata- } \\
\text { rata } \\
\%\end{array}$ \\
\hline Multidisipliner & $\begin{array}{l}\text { Integrasi } \\
\text { hakikat IPA }\end{array}$ & 6 & 5,4 & 5,7 & 4,6 & 14,8 & 9,7 \\
\hline Interdisipliner & Hubungan & 11,7 & 8,4 & 10,1 & 3,2 & 7 & 5,1 \\
\hline
\end{tabular}




\begin{tabular}{|c|c|c|c|c|c|c|c|}
\hline \multirow[b]{2}{*}{$\begin{array}{c}\text { Jenis } \\
\text { Integrasi }\end{array}$} & \multirow[b]{2}{*}{$\begin{array}{c}\text { Aspek } \\
\text { Keterpaduan }\end{array}$} & \multicolumn{3}{|c|}{ KTSP } & \multicolumn{3}{|c|}{ KURIKULUM 2013} \\
\hline & & $\begin{array}{l}\text { G1 } \\
\%\end{array}$ & $\begin{array}{c}\mathrm{G} 2 \\
\%\end{array}$ & $\begin{array}{c}\text { Rata- } \\
\text { rata } \\
\%\end{array}$ & $\begin{array}{c}\mathrm{G} 3 \\
\%\end{array}$ & $\begin{array}{c}\mathrm{G} 4 \\
\%\end{array}$ & $\begin{array}{c}\text { Rata- } \\
\text { rata } \\
\%\end{array}$ \\
\hline & $\begin{array}{l}\text { antara IPA dan } \\
\text { mata pelajaran } \\
\text { lainnya }\end{array}$ & & & & & & \\
\hline Transdisipliner & $\begin{array}{l}\text { Hubungan } \\
\text { pembelajaran } \\
\text { IPA dengan } \\
\text { kehidupan } \\
\text { sehari-hari dan } \\
\text { potensi daerah } \\
\text { setempat }\end{array}$ & 2,8 & 0 & 1,4 & 0,7 & 3,4 & 2,1 \\
\hline \multicolumn{2}{|c|}{ Jumlah } & 20,5 & 13,8 & 17,2 & 8,5 & 25,2 & 16,9 \\
\hline \multicolumn{2}{|c|}{ Rata-rata } & 6,8 & 4,6 & 5,7 & 2,8 & 8,4 & 5,6 \\
\hline
\end{tabular}

Analisis yang kedua, yaitu penguasaan konsep terpadu siswa pada sekolah yang menggunakan KTSP dan Kurikulum 2013 diukur dengan soal dalam bentuk dan jumlah yang sama. Soal diberikan kepada siswa setelah semua pembelajaran yang telah dijadwalkan selesai dilaksanakan oleh guru. Bentuk soal yang digunakan adalah pilihan ganda, berisi kaitan mata pelajaran IPA yaitu tentang sumber daya alam dengan mata pelajaran lain yaitu Bahasa Indonesia, Matematika, dan IPS. Materi yang dikaitkan dari mata pelajaran lain (Bahasa Indonesia, Matematika, dan IPS) disesuaikan dengan kompetensi yang sedang diajarkan bersamaan dengan materi sumber daya alam di mata pelajaran IPA. Penguasaan konsep terpadu ini diukur dengan menggunakan dimensi proses kognitif yang dikembangkan oleh Anderson dan Karthwol. Berdasarkan hasil uji coba dari 30 soal pilihan ganda, jumlah soal yang layak dipakai sebanyak 19 soal. Berikut ini adalah persentase rata-rata pencapaian penguasaan konsep terpadu dari setiap sekolah, dengan perhitungan jumlah skor siswa dibagi jumlah siswa dikali $100 \%$.

Tabel 2. Data Pencapaian Post Test soal penguasaan konsep terpadu

\begin{tabular}{|l|l|r|r|r|r|r|r|}
\hline \multirow{2}{*}{ No. } & \multirow{2}{*}{$\begin{array}{c}\text { Tingkatan } \\
\text { Kognitif }\end{array}$} & $\begin{array}{l}\text { G1 } \\
(\%)\end{array}$ & $\begin{array}{l}\text { G2 } \\
(\%)\end{array}$ & $\begin{array}{l}\text { Rata- } \\
\text { rata }\end{array}$ & $\begin{array}{l}\text { G3 } \\
(\%)\end{array}$ & $\begin{array}{l}\text { G4 } \\
(\%)\end{array}$ & $\begin{array}{l}\text { Rata- } \\
\text { rata }\end{array}$ \\
\cline { 3 - 9 } 1. & Mengingat & 79,0 & 69,4 & 74,2 & 70,5 & 76,0 & 73,3 \\
\hline 2. & Memahami & 64,0 & 58,3 & 61,2 & 59,3 & 60,6 & 60,0 \\
\hline 3. & Mengaplikasikan & 65,7 & 66,7 & 66,2 & 57,7 & 60,0 & 58,8 \\
\hline 4. & Menganalisis & 54,3 & 61,1 & 57,7 & 66,7 & 66,7 & 66,7 \\
\hline 5. & Mengevaluasi & 53,7 & 58,3 & 56,0 & 53,8 & 54,0 & 53,9 \\
\hline & Jumlah & 316,8 & 313,9 & 315,3 & 308,1 & 317,2 & 312,6 \\
\hline & Rata-rata & 63,4 & 62,8 & 63,1 & 61,6 & 63,4 & 62,5 \\
\hline
\end{tabular}




\section{PEMBAHASAN}

\section{Aspek Integrasi Hakikat IPA dalam Pembelajaran}

Fokus observasi pada aspek ini adalah kemunculan Keterampilan Proses Sains (KPS) dan sikap ilmiah dalam pembelajaran. Pada KTSP ciri dari keterampilan proses sains dan sikap ilmiah tertulis dalam standar kompetensi lulusan (SKL) untuk sekolah dasar yang tercantum dalam Permen Nomor 23 Tahun 2006 (hlm. 342) yaitu menunjukkan rasa keingintahuan yang tinggi dan menyadari potensinya, menunjukkan kemampuan memecahkan masalah sederhana dalam kehidupan sehari-hari, menunjukkan kemampuan mengenali gejala alam dan sosial di lingkungan sekitar, menunjukkan kecintaan dan kepedulian terhadap lingkungan. Selain tercantum pada SKL KPS dan sikap ilmiah juga muncul pada silabus KTSP yang diterbitkan oleh Depdiknas (2007, hlm. 68) di sana tercantum Standar kompetensi dan Kompetensi Dasar dari materi sumber daya alam.

Apabila kita melihat durasi kemunculan KPS dan sikap ilmiah dari guru yang mengajar di KTSP, dapat ditafsirkan bahwa KTSP sedikit memunculkan apabila dibandingkan dengan seluruh durasi pembelajaran yaitu 210 menit. Namun tidak demikian halnya apabila kita membandingkannya dengan silabus, terdapat 5 indikator yang mengarah pada KPS dan sikap ilmiah. Dari hasil pengamatan video, G1 dan G2 sudah memunculkan separuh indikator yang harus muncul yaitu klasifikasi dan komunikasi melalui kegiatan mengelompokkan sumber daya alam berdasarkan lingkungannya, persentase hasil diskusi dan menuliskan cara pembuatan ikan asap. Sedangkan untuk sikap ilmiah, indikator yang muncul adalah sikap berpikir terbuka dan kerja sama, yaitu terlihat dari partisipasi siswa dalam diskusi. Namun dalam mencari data dan informasi tentang hubungan sumber daya alam dengan lingkungan dan teknologi, guru di dua sekolah KTSP masih menggunakan metode ceramah sehingga siswa tidak memperoleh informasi secara mandiri. Menurut Sanjaya (2010, hlm. 179-180) metode ceramah (ekspositori) akan efektif apabila materi yang disampaikan berupa data atau fakta yang sudah jadi, data hasil penelitian ataupun konsepkonsep baru yang harus dihafal sehingga tidak menuntut siswa untuk berpikir ulang. Sedangkan seperti kita ketahui bahwa materi sumber daya alam bersifat kontekstual, artinya materi dapat siswa temukan dan kembangkan sendiri sumber daya alam yang ada di lingkungannya. Permasalahan ini di dukung oleh penelitian Subratha (2002, hlm. 10) yang mengungkapkan guru belum mampu mengembangkan sikap ilmiah yang ada pada diri siswa di sekolah dasar. Proses pembelajaran lebih didominasi oleh guru sebagai pemberi informasi, kurang memberikan kesempatan pada siswa mengembangkan sikap ilmiah seperti: sifat rasa ingin tahu, sikap objektif, sikap terbuka inisiatif, sikap jujur dan lain-lain. Namun setelah menerapkan pendekatan keterampilan proses (PKP) dalam pembelajaran IPA, ternyata sikap ilmiah siswa mengalami pengembangan. Kualitas sikap ilmiah siswa sebelum intervensi termasuk pada kategori cukup sedangkan setelah intervensi meningkat menjadi kategori baik. 
Hal tersebut menunjukkan bahwa penyebab lain dari sedikitnya kemunculan KPS dan sikap ilmiah adalah kurangnya pemahaman guru dalam mengembangkan KPS dan sikap ilmiah. Namun jika guru diberi pedoman dan dilatih pembelajaran yang mengembangkan KPS dan sikap ilmiah, guru sedikit demi sedikit dapat memahami dan menerapkan pembelajaran berbasis KPS dan sikap ilmiah. Seperti penelitian tindakan kelas yang dilakukan oleh Setiawan (2013, hlm.10) menunjukkan pengembangan keterampilan proses sains yang diakukan oleh guru pada siklus I, namun setelah di refleksi dan melakukan perbaikan keterampilan mengajar KPS guru meningkat pada siklus-siklus berikutnya. Kemampuan guru dalam melaksanakan pembelajaran melalui pendekatan keterampilan proses, yaitu tahap persiapan, pelaksanaan dan penutupan, mengalami kenaikan dari siklus 1 sampai dengan siklus 3 .

Pada aspek integrasi hakikat IPA, Kurikulum 2013 lebih banyak mengembangkan KPS dan sikap ilmiah dibandingkan dengan KTSP, bahkan untuk keterampilan proses juga muncul pada mata pelajaran lain. Berkaitan dengan KPS dan sikap ilmiah, dalam pelaksanaan pembelajaran Kurikulum 2013 pemerintah menetapkan pendekatan saintifik untuk diterapkan dalam langkahlangkah pembelajaran. Dalam pendekatan ini siswa dilatih melakukan kegiatan layaknya sebagai ilmuwan (scientist) dalam melakukan penyelidikan ilmiah. Oleh karena itu, pendekatan saintifik ini disebut juga dengan pembelajaran keterampilan proses sains yang dapat mengembangkan sikap ilmiah. Bentuk kegiatan pendekatan saintifik ini tertuang dalam Permendikbud Nomor 81A Tahun 2013 (hlm. 35-37) yaitu, mengamati, menanya, mengumpulkan informasi/eksperimen, mengasosiasikan/ mengolah informasi, mengomunikasikan. Selain itu KPS dan sikap ilmiah juga tersirat dalam kompetensi inti kelas IV dalam lampiran Permendikbud nomor 67 tahun 2013 tentang kerangka dasar dan struktur kurikulum SD/MI hlm. 8 yang menyatakan bahwa untuk aspek sikap sosial siswa kelas IV dapat menunjukkan perilaku jujur, disiplin, tanggung jawab, santun, peduli,dan percaya diri dalam berinteraksi dengan keluarga, teman, guru,dan tetangganya. Sedangkan untuk aspek pengetahuan siswa kelas IV dapat memahami pengetahuan faktual dengan cara mengamati dan menanya berdasarkan rasa ingin tahu tentang dirinya,makhluk ciptaan Tuhan dan kegiatannya, dan benda-benda yang dijumpainya di rumah,di sekolah dan tempat bermain. Kemudian untuk aspek keterampilan siswa kelas IV dapat menyajikan pengetahuan faktual dalam bahasa yang jelas, sistematis dan logis, dalam karya yang estetis, dalam gerakan yang mencerminkan anak sehat, dan dalam tindakan yang mencerminkan perilaku anak beriman dan berakhlak mulia.

Kompetensi inti tersebut diturunkan menjadi kompetensi dasar dan indikator. Pada penelitian proses pembelajaran yang diamati adalah tema 8 dengan mengambil lima pertemuan yang sesuai dengan tujuan penelitian. Pada lima pertemuan tersebut terdapat indikator-indikator dari setiap mata pelajaran. Peneliti tidak membatasi pengamatan pada mata pelajaran IPA, mengingat Kurikulum 2013 ini menggunakan pendekatan tematik integratif. Setelah dianalisis dari lima pertemuan tersebut terdapat 43 indikator dan 21 di antaranya adalah indikator yang mengarah pada indikator KPS. Kemudian dengan mengacu 
pada indikator-indikator tersebut peneliti membandingkannya dengan proses pembelajaran yang dilakukan oleh guru yaitu G3 dan G4, ternyata dari 21 indikator G3 dapat memunculkan 8 indikator (38\%) sedangkan G4 dapat memunculkan 12 indikator (57\%).

Dari pemaparan di atas dapat diketahui bahwa jika proses pembelajaran dibandingkan dengan indikator-indikator pembelajaran yang mengarah pada indikator KPS dan sikap ilmiah, baik guru KTSP maupun Kurikulum 2013 dapat memunculkan rata-rata $50 \%$ indikator pembelajaran. Namun jika durasi kemunculan KPS dan sikap ilmiah dibandingkan dengan durasi keseluruhan, baik guru KTSP maupun Kurikulum 2013 hanya dapat memunculkan sedikit indikator tersebut. Hal tersebut dimungkinkan mengingat yang subjek yang peneliti amati adalah guru, sehingga yang dianggap sebagai satu kemunculan adalah apa yang dikatakan atau diperbuat guru dalam memunculkan indikator KPS dan sikap ilmiah. Sedangkan respon siswa terhadap instruksi yang diberikan guru tidak dihitung sebagai suatu kemunculan.

Disamping itu pola mengajar guru yang masih memprioritaskan aspek kognitif bisa jadi penyebab rendahnya kemunculan KPS dan sikap ilmiah. Seperti penelitian yang dilakukan oleh Rochintaniawati (2009, hlm. 7) mengungkapkan bahwa dimensi pengetahuan yang dikembangkan guru dalam pembelajaran berdasarkan hasil pengamatan hanya pada aspek kognitif. Kenyataan ini didukung oleh hasil angket sebagai berikut: $70 \%$ guru menyatakan bahwa hal yang paling penting dalam mempelajari IPA adalah memahami konsep-konsep IPA dan $78 \%$ guru yang menyatakan bahwa percobaan atau kegiatan IPA dalam pembelajaran IPA dianggap penting dengan alasan untuk lebih memahami materi IPA. Tidak ada satu pun jawaban yang menyatakan bahwa aspek psikomotorik dan afektif perlu dikembangkan dalam pembelajaran. Kenyataan ini menunjukan masih kurangnya pemahaman guru terhadap hakikat IPA, bahwa pembelajaran IPA terutama di sekolah dasar tidak hanya bertujuan agar siswa memahami konsepkonsep IPA (produk IPA) tetapi juga untuk mengajak siswa melakukan kegiatan pengamatan, berinkuiri dan menanamkan sikap dengan tujuan untuk menumbuhkan keingintahuan siswa,meningkatkan keterampilan berpikir siswa (keterampilan berpikir kreatif dan kritis) dan melatih tangan siswa untuk bekerja agar siswa menjadi pembelajar yang mandiri sebagai bekal untuk hidup di masyarakat.

Jadi dapat disimpulkan bahwa guru mengajar IPA secara konvensional. Padahal baik KTSP maupun Kurikulum 2013 menghendaki pembelajaran IPA itu dilakukan secara terpadu. Salah satunya mengintegrasikan sikap dan keterampilan, didasarkan pada pendapat yang dikemukakan Drake dan Burns (dalam Abidin, 2014:211) di mana salah satu jenis pembelajaran integrasi adalah multidisipliner, dalam multidisipliner tersebut terdapat ciri fuse, yakni pembelajaran yang menyatukan keterampilan, pengetahuan dan sikap tertentu dalam kurikulum sekolah. Misalnya, keterampilan proses sains dan sikap ilmiah yang disatukan dengan berbagai mata pelajaran di sekolah.

Berdasarkan data penelitian, teori dan penelitian terdahulu dapat disimpulkan bahwa baik guru di KTSP dan Kurikulum 2013 masih sedikti dalam memunculkan KPS dan sikap ilmiah dalam pembelajaran. Hal ini disinyalir 
karena guru belum banyak memahami terkait dengan keterampilan proses sains dan sikap ilmiah. Sehingga belum dapat menerapkannya secara optimal dalam pembelajaran dan pembelajaran cenderung konvensional. Namun begitu jika guru diberi pemahaman dan pedoman untuk menerapkan KPS dan sikap ilmiah di kelas, peneliti yakin bahwa kemampuan guru dalam mengembangkan KPS dan sikap ilmiah akan semakin meningkat. Mudah-mudahan ke depan akan semakin banyak lagi penelitian yang menyoroti tentang KPS dan sikap ilmiah baik dengan subyek penelitian guru maupun siswa. Dengan begitu akan memberikan kontribusi yang banyak terhadap kemampuan mengajar KPS dan sikap ilmiah guru.

\section{Aspek Hubungan IPA dengan Mata Pelajaran Lain}

Dari tabel 1 analisis aspek hubungan antara mata pelajaran IPA dengan mata pelajaran lainnya, dapat diketahui bahwa pada jumlah rata-rata persentase KTSP lebih tinggi dari Kurikulum 2013. Hal ini dikarenakan susunan materi IPA dan IPS KTSP semester dua terdapat kemiripan yaitu tentang materi sumber daya alam, namun sumber daya alam pada IPS lebih kepada pemanfaatannya untuk kegiatan ekonomi dan juga membahas pengolahannya secara sederhana dan modern. Oleh karena itu dalam pembelajarannya guru secara tidak langsung dan tanpa disadari telah memunculkan kaitan mata pelajaran IPA dengan IPS. Jadi dapat dikatakan telah terjadi tumpang tindih antara materi IPA dan IPS. Hal tersebut dikuatkan dengan Permen Nomor 22 tahun 2006 (hal. 6) tentang prinsip pelaksanaan kurikulum disebutkan bahwa kurikulum yang mencakup seluruh komponen kompetensi mata pelajaran, muatan lokal dan pengembangan diri diselenggarakan dalam keseimbangan, keterkaitan, dan kesinambungan yang cocok dan memadai antar kelas dan jenis serta jenjang pendidikan.

Tumpang tindih antara beberapa mata pelajaran juga merupakan salah satu alasan diterapkannya tematik terpadu pada semua jenjang kelas di Kurikulum 2013. Menurut Kemendiknas (2013) berdasarkan pengalaman belajar dalam Kurikulum sebelumnya, yang cenderung disipliner, sarat beban materi kognitif, over lapping antar materi yang sama di mata pelajaran berbeda, antara lain salah satu sebab perlunya pembelajaran tematik terpadu penting diterapkan sejak di SD. Oleh Pengembang Kurikulum 2013 diyakini bahwa pembelajaran tematik terpadu merupakan sebagai salah satu model pengajaran yang efektif (highly effective teaching model). Sejalan dengan pendapat tersebut, Depdikbud (dalam Musfah, 2012, hlm. 187) pembelajaran terpadu memungkinkan siswa untuk memahami suatu fenomena dari segala sisi. Hal tersebut dikarenakan dalam pembelajaran terpadu siswa mengkaji dan mengmati suatu gejala atau fenomena dari dari beberapa bidang kajian sekaligus, tidak dari sudut pandang yang terkotak-kotak. Pada gilirannya nanti hal itu akan membuat siswa menjadi lebih arif dan bijaksana dalam menyikapi atau menghadapi kejadian yang ada di depan mereka. Mengajarkan IPA secara terpadu memang sudah ada dalam KTSP sesuai dengan Permendiknas No. 22 Tahun 2006 (hlm. 6) yang menyatakan bahwa Substansi mata pelajaran IPA dan IPS pada SD/MI merupakan "IPA Terpadu" dan "IPS Terpadu". IPA terpadu disini dalam bentuk intradisipliner, yakni memadukan mata pelajaran fisika, kimia dan biologi. Namun pada jenjang sekolah dasar IPA 
terpadu tidak terlalu tampak karena materi IPA yang dipelajari masih bersifat umum dan belum spesifik.

Dari tabel 1 analisis aspek hubungan antara mata pelajaran ipa dengan mata pelajaran lainnya, dapat diketahui bahwa pada jumlah rata-rata persentase Kurikulum 2013 lebih kecil dibandingkan dengan KTSP. Hal ini terjadi karena peneliti hanya mengamati keterkaitan IPA dengan mata, pelajaran lain, sedangkan dalam lima pertemuan tersebut terdapat juga keterkaitan antar mata pelajaran yang lainnya. Seperti pada pertemuan 3 terdapat keterkaitan matematika dan bahasa Indonesia, yaitu menemukan informasi yang sesuai dari peta koordinat suatu tempat. Pertemuan 5 keterkaitan antara IPS dan PKn untuk PKn indikatornya menjelaskan manfaat kegiatan bekerja sama dan mengidentifikasi kegiatan kerja sama di lingkungan pedesaan dan IPS dengan indikator menyimpulkan nilai yang diperoleh dari kegiatan berinteraksi dengan budaya dan masyarakat. Ada pula keterkaitan antara IPA dengan mata pelajaran lain tetapi tidak sesuai dengan indikator-indikator mata pelajaran yang digunakan pada pertemuan saat itu. Jadi peneliti menentukan satu kemunculan hanya jika sesuai dengan mata pelajaran dan indikator yang sudah ditentukan pada pembelajaran saat itu.

Keterkaitan antar mata pelajaran ini sesuai dengan Permen Nomor 67 Tahun 2013 (hlm. 33) salah satu ciri tematik integratif Kurikulum 2013 adalah Integrasi interdisipliner dilakukan dengan menggabungkan kompetensikompetensi dasar beberapa mata pelajaran agar terkait satu dengan yang lainnya, sehingga dapat saling memperkuat, menghindari terjadinya tumpang tindih, dan menjaga keselarasan pembelajaran. Hal ini sejalan dengan pendapat Majid (2014, hlm. 56) bahwa pembelajaran terpadu membantu siswa membentuk "file" mendorong keterkaitan dan pemahaman lebih dalam terhadap konsep atau makna serta keterampilan yang telah dipelajari oleh siswa. Dengan demikian transfer pemahaman dapat terjadi dari satu konteks ke konteks lainnya. Pembelajaran IPA dengan pendekatan terpadu, yaitu dengan cara mengaitkan mata pelajaran IPA dengan mata pelajaran lainnya, pada akhirnya akan memberikan kemampuan pada siswa untuk berpikir holistik.

Selain itu dalam pembelajaran selama lima pertemuan tersebut terdapat juga mata pelajaran yang berdiri sendiri, hal ini sesuai dengan Permen Nomor 67 Tahun 2013 (hlm. 133) ciri lain dari tematik integratif Kurikulum 2013 adalah Integrasi multidisipliner dilakukan tanpa menggabungkan kompetensi dasar tiap mata pelajaran sehingga tiap mata pelajaran masih memiliki kompetensi dasarnya sendiri. G3 dan G4 dalam pembelajaran sepenuhnya mengikuti buku panduan guru. Jadi dapat dikatakan bahwa G3 dan G4 belum tentu memahami tentang pembelajaran terpadu baik itu menurut teori ahli maupun tuntutan kurikulum sendiri. Aspek keterkaitan antara IPA dengan mata pelajaran lainnya itu bisa muncul karena aspek tersebut sudah ada dalam buku panduan guru dan guru tinggal mengikutinya. Jika memang guru sudah sangat mengerti tentang esensi pembelajaran tematik integratif yang dituntut dalam kurikulum 2013, maka guru akan dapat memunculkan aspek hubungan IPA dengan mata pelajaran lainnya dengan persentase lebih besar. Guru akan lebih peka dan teliti dalam melihat kesempatan dan kemungkinan dapat memunculkan kaitan IPA dengan mata pelajaran lain di setiap langkah pembelajaran. 
Pada dasarnya baik pembelajaran yang dilakukan secara terpisah maupun terpadu dapat memuat kaitan materi IPA dengan mata pelajaran lainnya yaitu Bahasa Indonesia, IPS, Matematika dan SBK. Pada KTSP seharusnya mata pelajaran IPA berdiri sendiri namun pada kenyataannya materi IPA tumpang tindih dengan IPS sehingga dapat membentuk keterkaitan antara mata pelajaran IPA dengan IPS. Sedangkan untuk Kurikulum 2013 bentuk integrasi mata pelajaran tidak hanya antar mata pelajaran saja (interdisipliner) tapi juga dalam bentuk intra-disipliner, multi-disipliner, dan trans-disipliner. Guru dituntut untuk memahami atau mengerti apa yang diajarkan, maka dalam kurikulum 2013 guru sebagai pelaksana kurikulum harus memahami tentang pembelajaran terpadu baik dalam hal konsep pembelajaran terpadu maupun prosedur pembelajaran terpadu yang meliputi penyusunan, perencanaan, pelaksanaan dan evaluasi. Namun begitu meskipun guru belum dapat memahami dan menjalankan pembelajaran secara utuh/terpadu, adanya buku panduan guru diharapkan dapat membantu guru untuk dapat menerapkan pembelajaran tematik terpadu dengan lebih baik sesuai dengan tuntutan kurikulum. Guru memang ujung tombak agen perubahan, namun guru tidak serta merta dapat adaptif terhadap setiap tuntunan perubahan. Bagaimanapun harus ada keseriusan dan kesinambungan bahwa guru bukan satu-satunya sosok penanggung jawab sentral akan keberhasilan Kurikulum 2013. Hal ini karena penerapan sistem pendidikan nasional adalah mata rantai dimana dibutuhkan "kerja sama tim" yang padu.

\section{Aspek Hubungan IPA dengan Kehidupan Sehari-Hari dan Potensi Daerah Setempat}

Pada tabel 1 analisis kemunculan aspek hubungan pembelajaran ipa dengan kehidupan sehari-hari dan potensi daerah setempat, menunjukkan bahwa guru di KTSP masih sedikit dalam memunculkan kaitan materi dengan kehidupan sehari-hari dan potensi daerah. Padahal seperti yang kita ketahui bahwa KTSP merupakan kurikulum yang memberikan keleluasaan pada setiap satuan pendidikan untuk mengembangkan materi pelajaran sesuai dengan karakteristik kehidupan masyarakat di daerahnya masing-masing. Hal ini tercantum dalam Permen Nomor 22 Tahun 2006 (hal 5) tentang prinsip pengembangan kurikulum, bahwa pengembangan kurikulum dilakukan dengan melibatkan pemangku kepentingan (stakeholders) untuk menjamin relevansi pendidikan dengan kebutuhan kehidupan, termasuk di dalamnya kehidupan kemasyarakatan,dunia usaha dan dunia kerja. KTSP juga memanfaatkan lingkungan sekitar sebagai sumber belajar, dengan prinsip alam takambang jadi guru (semua yang terjadi, tergelar dan berkembang di masyarakat dan lingkungan sekitar serta lingkungan alam semesta dijadikan sumber belajar, contoh dan teladan). Kurikulum dilaksanakan dengan mendayagunakan kondisi alam, sosial dan budaya serta kekayaan daerah untuk keberhasilan pendidikan dengan muatan seluruh bahan kajian secara optimal. Selain itu dalam acuan operasional penyusunan kurikulum tingkat satuan pendidikan,keragaman potensi dan karakteristik daerah dan lingkungan sangat diperhatikan karena daerah memiliki potensi, kebutuhan, tantangan, dan keragaman karakteristik lingkungan. Dari uraian tersebut dapat 
diketahui bahwa KTSP sangat mengharapkan guru dapat mengusung potensi daerah dan melibatkan kehidupan sehari-hari siswa dalam pembelajaran.

Namun pada kenyataannya G1 hanya dapat memunculkan sedikit indikator dari aspek tersebut, bahkan G2 tidak dapat memunculkannya sama sekali. Hal ini disebabkan guru terlalu mengandalkan buku teks dalam pembelajaran dan fokus untuk menyelesaikan materi tanpa ada usaha untuk mengaitkan materi baik dengan kehidupan sehari-hari siswa maupun potensi daerah setempat. Guru seharusnya dapat memfasilitasi siswa untuk terlibat dalam pembelajaran dan memperoleh pengetahuannya secara mandiri. Tim MKDP (2006, hlm. 147) yang menyatakan bahwa mengajar bukan hanya transformasi pengetahuan dari guru kepada siswa dengan menghafal sejumlah konsep-konsep yang sepertinya terlepas dari kehidupan nyata, akan tetapi lebih ditekankan pada upaya memfasilitasi siswa untuk mencari kemampuan untuk bisa hidup (life skill) dari apa yang dipelajari. Dengan demikian pembelajaran akan lebih bermakna, sekolah lebih dekat dengan lingkungan masyarakat (bukan dekat dari segi fisik), akan tetapi secara fungsional apa yang dipelajari di sekolah senantiasa bersentuhan dengan situasi dan permasalahan kehidupan yang terjadi di lingkungannya (keluarga dan masyarakat).

Pada pembelajaran yang dilakukan di sekolah yang menggunakan Kurikulum 2013. Pembelajaran yang dilakukan oleh G3 dapat memunculkan indikator kehidupan sehari-hari yaitu sebanyak 15 kali (5 menit). Sementra itu, G4 dapat memunculkan kedua indikator sebanyak 43 kali (14,3 menit). Dalam kurikulum 2013 aspek hubungan pembelajaran ipa dengan kehidupan sehari-hari dan potensi daerah setempat tercermin dalam Permen No 67 Tahun 2013 (hlm. 133) salah satu ciri tematik integratif adalah integrasi trans-disipliner dilakukan dengan mengaitkan berbagai mata pelajaran yang ada dengan permasalahanpermasalahan yang dijumpai di sekitarnya sehingga pembelajaran menjadi kontekstual. Kontekstual merupakan suatu konsep belajar di mana guru menghadirkan situasi dunia nyata ke dalam kelas dan mendorong siswa membuat hubungan antara pengetahuan yang dimilikinya dengan penerapannya dalam kehidupan mereka sebagai anggota keluarga dan masyarakat. Dengan konsep ini, hasil pembelajaran diharapkan lebih bermakna bagi siswa. Proses pembelajaran berlangsung lebih alamiah dalam bentuk kegiatan siswa bekerja dan mengalami, bukan transfer pengetahuan dari guru ke siswa. Sejalan dengan pendapat Majid (2014, hlm. 179) bahwa pembelajaran secara kontekstual adalah suatu proses pendidikan yang holistik dan bertujuan memotivasi siswa untuk memahami makna materi pelajaran yang dipelajarinya dengan mengaitkan materi tersebut dengan konteks kehidupan mereka sehari-hari sehingga siswa memiliki pengetahuan/keterampilan yang secara fleksibel dapat diterapkan (ditransfer) dari suatu permasalahan/konteks ke permasalahan/konteks lainnya.

Sangat disayangkan sekali baik itu guru KTSP maupun Kurikulum 2013 hanya dapat memunculkan sedikit aspek hubungan IPA dengan kehidupan seharihari dan potensi daerah. Padahal materi yang diajarkan adalah tentang sumber daya alam yang sudah tentu dapat ditemui siswa dalam kehidupan sehari-hari. Namun sepertinya guru belum begitu memahami tentang pentingnya mengajar dengan kontekstual. Terkait dengan hal tersebut, penelitian yang dilakukan oleh 
Suryanti (2006, hlm. 6) menyatakan bahwa faktor utama yang menghambat implementasi pembelajaran kontekstual di kelas adalah guru yang belum menguasai keterampilan dasar mengajar dan keterampilan dasar pengelolaan pembelajaran.

Kurangnya usaha guru dalam melakukan pembelajaran secara kontekstual juga berdampak pada keterlibatan siswa dalam pembelajaran. Pengalaman Shipiwelas (2013, hlm. 2) sebagai guru kelas IV menemukan bahwa keterlibatan siswa secara aktif dalam pembelajaran IPA rendah. Rendahnya keterlibatan siswa secara aktif dalam pembelajaran IPA disebabkan guru mengajar hanya menggunakan metode ceramah saja. Salah satu alasan menggunakan metode ceramah adalah perasaan tidak puas jika dalam pembelajaran tidak melakukan ceramah. Demikian juga siswa, mereka akan belajar manakala ada guru yang berceramah. Pembelajaran dianggap terjadi kalau ada ceramah, tanpa ceramah dianggap bukan pembelajaran. Untuk itu Shipiwelas melakukan penelitian untuk mengatasi hal tersebut dengan menggunakan pembelajaran kontekstual.

Pembelajaran yang dilaksanakan secara kontekstual, lebih bermanfaat baik untuk siswa maupun guru karena memiliki beberapa keunggulan. Seperi pendapat yang dikemukakan oleh Wahyuni $(2013$, hlm. 7) bahwa pembelajaran secara kontekstual didukung dengan beberapa keunggulan, salah satunya adalah pembelajaran menjadi lebih bermakna dan riil. Selain itu model pembelajaran kontekstual dalam penerapannya juga memiliki kelebihan yaitu bagi guru dapat membantu guru mengaitkan materi yang sedang dipelajari dengan situasi dunia nyata siswa, sedangkan bagi siswa model pembelajaran kontekstual ini dapat membuat siswa mengaitkan pengetahuan yang sudah dimilikinya (budaya lokal) dengan penerapannya dalam kehidupan sehari-hari sehingga siswa lebih cepat mengerti dan pembelajaran yang dilaksanakan menjadi lebih bermakna. Sehingga dapat membantu siswa dalam pencapaian pemahaman yang lebih baik terhadap konsep IPA. Hal ini sesuai dengan teori belajar bermakna yang dikemukakan Ausubel (dalam Dahar, 2013: 65) yang menyatakan belajar akan bermakna apabila siswa dapat mengaplikasikan pelajarannya dalam kehidupan nyata.

Jika membandingkan antara data kemunculan dengan tuntutan kurikulum dan teori, dapat disimpulkan bahwa guru baik di KTSP maupun Kurikulum 2013 belum optimal dalam menggali materi berdasarkan potensi daerah dan kehidupan sehari-hari. Padahal jika guru mengetahui dan memahami bagaimana pentingnya pembelajaran kontekstual baik yang tercantum dalam kurikulum maupun teori, maka sudah seharusnya pembelajaran yang dilakukan oleh guru dimulai dengan kehidupan sehari-hari siswa dan materi didominasi oleh keadaan lingkungan dan potensi daerah setempat.

\section{Penguasaan Konsep Terpadu}

Data nilai siswa digunakan untuk uji kesamaan rerata. Analisis uji kesamaan rerata hasil tes bertujuan memeriksa ada tidaknya perbedaan yang signifikan penguasaan konsep terpadu antara kelas KTSP dan kurikulum 2013. Uji kesamaan 
rerata ini dilakukan dengan uji t' karena data yang dihasilkan normal namun tidak homogen. Hipotesis yang digunakan pada uji kesamaan rerata skor gain adalah:

$\mathrm{H}_{0}$ : skor penguasaan konsep terpadu yang menggunakan KTSP lebih baik daripada skor penguasaan konsep terpadu siswa yang menggunakan kurikulum 2013

H1 : skor penguasaan konsep terpadu yang menggunakan KTSP tidak lebih baik daripada skor penguasaan konsep terpadu siswa yang menggunakan kurikulum 2013

Kriteria penerimaan hipotesis statistik:

$\mathrm{H}_{0}: \mu_{1} \leq \mu_{2}$

$\mathrm{H}_{1}=\mu_{1}>\mu_{2}$

Untuk mengambil keputusan dilakukan dengan cara membandingkan nilai asynp.signya dengan $\alpha=0,05$. Dari hasil perhitungan diperoleh asymp.signya $=$ 0,680 lebih besar dari $\alpha=0,05$, yang berarti $\mathrm{H}_{0}$ diterima dan $\mathrm{H}_{1}$ ditolak. Berdasarkan hal itu dapat disimpulkan bahwa penguasaan konsep terpadu yang menggunakan KTSP lebih baik daripada skor penguasaan konsep terpadu siswa yang menggunakan kurikulum 2013.

Apabila melihat hasil persentase kemunculan aspek keterpaduan guru KTSP pada tabel 2, G1 persentase kemunculan aspek keterpaduan sebesar 6,8\% pada aspek hubungan anatara IPA dengan mata pelajaran lainnya G1 memperoleh persentase paling tinggi diantara guru lainnya yaitu sebesar $11,7 \%$ sehingga ratarata persentase pengusaan konsep terpadu untuk siswa G1 termasuk pada kategori sedang yaitu sebesar $63,4 \%$. G2 memperoleh rata-rata persentase kemunculan aspek keterpaduan sebesar 4,6\% dalam pembelajaran G2 tidak memunculkan aspek hubungan IPA dengan kehidupan sehari-hari dan potensi daerah, walaupun demikian hasil rata-rata nilai siswa G2 termasuk pada kategori sedang yaitu sebesar $61,6 \%$.

Sedangkan untuk guru Kurikulum 2013, G3 persentase kemunculan aspek keterpaduan memperoleh rata-rata sebesar 2,8\% angka ini adalah persentase paling kecil di antara guru-guru lainnya. G2 hanya dapat memunculkan sedikit aspek keterpaduan dalam pembelajaran, namun rata-rata nilai untuk siswa G3 termasuk pada kategori sedang yaitu sebesar $62,8 \%$. Guru yang terakhir adalah G4, rata-rata persentase untuk kemunculan aspek keterpaduan adalah 8,4\% angka ini adalah perolehan tertinggi di antara guru-guru yang lainnya. Dari hasil observasi pembelajaran G4 dapat memunculkan aspek keterpaduan dengan cukup baik dan hasil rata-rata nilai siswa G4 pun termasuk pada kategori sedang yaitu sebesar $63,4 \%$.

Hasil perbandingan antara proses dan hasil pembelajaran menunjukkan bahwa proses pembelajaran yang dilakukan oleh guru tidak mempengaruhi secara signifikan terhadap pencapaian nilai siswa. Hal ini terlihat dari rata-rata nilai siswa untuk G1 dan G4 adalah sama yaitu 63,4\% padahal persentase kemunculan aspek keterpaduan G4 lebih tinggi daripada G1. Selain itu walaupun G3 memperoleh persentase kemunculan aspek keterpaduan paling rendah di antara guru lainnya tetapi rata-rata nilai siswa G3 tidak terpaut jauh dengan rata-rata nilai G1, G2 dan G4. Temuan tersebut menunjukkan bahwa guru bukanlah satusatunya komponen yang dapat menentukan keberhasilan belajar siswa. Banyak 
faktor yang dapat mendukung keberhasilan belajar siswa di antaranya, faktor internal seperti kemauan siswa untuk membaca dan memperoleh informasi lebih banyak tentang materi sumber daya alam, faktor eksternal seperti sumber belajar yang tersedia di sekolah atau les tambahan di luar jam sekolah yang dapat menambah wawasan siswa tentang materi sumber daya alam. Hal ini diperkuat dengan pendapat Tirtaharja dan Sulo (2005, hlm. 254) yang menyatakan bahwa guru mendudukan dirinya hanya sebagai bagian dari sumber belajar. Beraneka ragam sumber belajar yang hanya justru dapat ditemukan di luar diri guru seperti, perpustakaan, taman bacaan, museum, toko buku, berbagai media masa, lembagalembaga sosial, orang-orang pintar, alam dan lingkungan sekitar.

Selain itu soal dibuat oleh peneliti dari materi buku teks siswa dan dibuat sebelum guru melakukan pembelajaran. Sehingga soal yang dibuat tidak disesuaikan dengan materi yang diajarkan oleh guru. Oleh karena itu siswa bisa saja dapat menjawab soal karena rajin membaca buku teks. Hal lain yang patut dipertimbangkan adalah sifat materi sumber daya alam. Sumber daya alam adalah materi yang kontekstual sehingga walaupun guru tidak memberikan materi sepenuhnya, siswa dapat menemukan contoh-contoh dan aplikasi teori sumber daya alam dalam kehidupan sehari-hari di lingkungan mereka. Hal tersebut membantu siswa untuk menjawab soal-soal terpadu tentang sumber daya alam dengan baik. Namun begitu, tidak dapat dipungkiri bahwa guru juga memberikan kontribusi pada cara belajar siswa. Misalnya, guru mengingatkan siswa untuk rajin membaca, teliti dalam mengerjakan soal, dan memotivasi siswa untuk aktif bertanya di kelas. Karena pada dasarnya tugas guru adalah memfasilitasi siswa untuk belajar. Seperti yang dikemukakan oleh Tirtaharja dan Sulo (2005, hlm. 254) bahwa tugas guru bukan memberikan ilmu pengetahuan melainkan menunjukkan jalan bagaimana cara memperoleh ilmu pengetahuan dan mengembangkan dorongan untuk berilmu.

\section{E. SIMPULAN}

Berdasarkan penelitian yang telah dilakukan kemunculan aspek keterpaduan dan penguasaan konsep terpadu siswa kelas IV SD melalui KTSP dan kurikulum 2013, dapat disimpulkan bahwa, Pertama, baik KTSP maupun Kurikulum 2013 masih sedikit dalam memunculkan aspek keterpaduan, hal tersebut terlihat dari persentase rata-rata kemunculan hanya di bawah $15 \%$. Oleh karena itu dapat dikatakan bahwa kemampuan guru dalam memunculkan aspek keterpaduan baik di KTSP maupun Kurikulum 2013 cenderung sama walaupun kurikulum yang digunakan berbeda. Kedua, dari hasil uji t' dapat disimpulkan bahwa penguasaan konsep terpadu yang menggunakan KTSP lebih baik daripada skor penguasaan konsep terpadu siswa yang menggunakan kurikulum 2013. Kesimpulan dalam penelitian ini bahwa pembelajaran terpadu tidak hanya dalam kurikulum 2013 saja, tetapi dalam KTSP pun yang pembelajarannya masih disipliner pembelajaran terpadu dapat dimunculkan.

\section{DAFTAR RUJUKAN}

Abidin, Y. (2014). DesainSistemPembelajarandalamKonteksKurikulum 2013.Bandung: PT. RefikaAditama 
Majid, A. 2014. Pembelajaran Tematik Terpadu. Bandung: PT. RemajaRosdaKarya

Maryeni. dkk. (2014). Analisis Tingkat Pemahaman Guru Sekolah DasarTentang Pembelajaran Terpadu Pada Kurikulum 2013. Jurnal Fakultas Keguruan Dan Ilmu Pendidikan Universitas Lampung .Tersedia:download.portalgaruda.org/article.php?article $=288730 \&$ val $=723$ 9\&title=PEMAHAMAN GURU SEKOLAH DASAR TENTANG PEMBELAJARAN TERPADU PADA KURIKULUM 2013.[18 Mei 2015]

Musfah, J .(2012). PendidikanHolistik.Jakarta: KencanaPrenada Media Group

Pudjiastuti, A. (2011). Permasalahan Penerapan Pembelajaran Tematik di Kelas Awal Sekolah Dasar. Disertasi, Universitas Negeri Malang.

Peratuaran Mentri Pendidikan Nasional Nomor 23 Tahun 2006 tentang Standar Kompetensi Lulusan Satuan Pendidikan Dasar dan Menengah.

Permendikbud No. 54 Tahun 2013 tentang Standar Kompetensi Lulusan Pendidikan Dasar dan Menengah

Permendikbud No. 65 Tahun 2013 tentang Standar Proses Pendidikan Dasar dan Menengah

Permendikbud No. 67 Tahun 2013 tentang Kerangka Dasar dan Struktur Kurikulum Sekolah Dasar/Madrasah Ibtidaiyah

Rochintaniawati, D. dkk. (2006). Kebutuhan Guru Sekolah Dasar Di Cimahi Dan KabupatenBandung Dalam Melangsungkan Pembelajaran IPA.JURNAL PENDIDIKAN DASAR, VOL.7, NO.1, 2006: 50-60 50 http://journal.unnes.ac.id

Samsuri. (2013). Kebijakan Pembelajaran Tematik Terpadu Kurikulum 2013. Pengantar Kuliah Umum Universitas Negeri Malang.

Sanjaya, W. (2010). Strategi Pembelajaran Berorientasi Standar Proses Pendidikan. Jakarta: Prenada Media Group

Shipiwelas, H. (2013). Peningkatan Keterlibatan Siswa Secara Aktif Dalam Pembelajaran Ipa Menggunakan Pendekatan Kontekstual Pada Siswa Kelas IV . Program Studi Pendidikan Dasar (Volume 3 Tahun 2013)

Subrata, I. N.,dkk (2002) Upaya Meningkatkan Sikap Ilmiah dan Kualitas Hasil Belajar Siswa Sekolah Dasar Melalui Pembelajaran IPA dengan Pendekatan Keterampilan Proses. Jurnal Pendidikan dan Pengajaran IKIP Negeri Singaraja No.2 Th. XXXV April 2002.

Yani, A. (2013). Mindset Kurikulum 2013. Bandung: Alfabeta. 